\title{
Nucleotide-Binding Oligomerization Domain-Containing Protein 1
}

National Cancer Institute

\section{Source}

National Cancer Institute. Nucleotide-Binding Oligomerization Domain-Containing

Protein 1. NCl Thesaurus. Code C113088.

Nucleotide-binding oligomerization domain-containing protein 1 (953 aa, $108 \mathrm{kDa}$ ) is encoded by the human NOD1 gene. This protein plays a role in both apoptosis and hostdefense responses. 